\title{
New report of fossil crabs (Decapoda, Brachyura) from the late Eocene of San Feliciano Hill (Orgiano, Monti Berici, Vicenza, NE Italy)
}

\section{Nuevo reporte de cangrejos (Decapoda, Brachyura) fósiles del Eoceno tardío en San Feliciano Hill (Orgiano, Monte Bérico, Vicenza, NE de Italia)}

Antonio De Angeli ${ }^{1}$, Alessandro Garassino ${ }^{2, *}$

${ }^{1}$ Museo Civico G. Zannato, Montecchio Maggiore, Vicenza, Italy.

${ }^{2}$ Department of Earth and Biological Sciences, Loma Linda University, Loma Linda, CA 92350, USA.

* Corresponding author: (A. Garassino) alegarassino@gmail.com

\section{How to cite this article:}

De Angeli, A., Garassino, A., 2021, New report of fossil crabs (Decapoda, Brachyura) from the late Eocene of San Feliciano Hill (Orgiano, Monti Berici, Vicenza, NE Italy): Boletín de la Sociedad Geológica Mexicana, 73 (3), A120221. http://dx.doi.org/10.18268/ BSGM2021v73n3a120221

Manuscript received: January 8, 2021

Corrected manuscript received: May 5, 2021

Manuscript accepted: May 12, 2021

Peer Reviewing under the responsibility of Universidad Nacional Autónoma de México.

This is an open access article under the CC BY-NC-SA license(https://creativecommons.org/licenses/by-nc-sa/4.0/)

\section{ABSTRACT}

The rich decapod assemblage from the late Eocene of San Feliciano hill (Orgiano, Monti Berici, Vicenza, NE Italy) was partially recorded by De Angeli and Garassino (2002, 2014). Herein, two new crabs, Bericirinia bretoni n. gen., n. sp. (Epialtidae MacLeay, 1838) and Orgianocarcinus bericus n. gen., n. sp. (Dairidae Ng and Rodriguez, 1986) are reported from San Feliciano Hill, located in Monti Berici, Orgiano. Moreover, two well-preserved specimens assigned to Actaeites lobatus Müller and Collins, 1991 Xanthoidea MacLeay, 1838, incertae sedis) allowed to add some morphological characters to the original description of the holotype, lacking the fronto-orbital margin.

Keywords: Crustacea, Decapoda, Brachyura, Epialtidae, Dairidae, Xanthoidea, taxonomy, late Eocene, Italy.

\section{RESUMEN}

El rico conjunto de decápodos del Eoceno tardío del cerro San Feliciano (Orgiano, Monte Bérico, Vicenza, NE Italia) fue registrado parcialmente por De Angeli y Garassino (2002, 2014). En esta zona hay dos nuevos cangrejos, Bericirinia bretoni $n$. gen., n. sp. (Epialtidae MacLeay, 1838) y Orgianocarcinus bericus $n$. gen., n. sp. (Dairidae $\mathcal{N g}$ y Rodríguez, 1986) encontrados en el cerro San Feliciano, localizado en Orgiano del Monte Bérico. Además estos dos ejemplares estan bien conservados y asignados para Actaeites lobatus Müller y Collins, 1991 (Xanthoidea MacLeay, 1838, incertae sedis) lo que permitió añadir algunos caracteres morfológicos a la descripción original del holotipo donde se carece del margen frontoorbitario.

Palabras clave: Crustacea, Decapoda, Brachyura, Epialtidae, Dairidae, Xanthoidea, taxonomia, Eoceno tardío, Italia. 


\section{Introduction and geological setting}

San Feliciano hill is located on the southwestern side of Monti Berici between Orgiano and Lonigo (Figure 1). The studied specimens are preserved within the limestones including coralline algae and corals from the late Eocene (Priabonian), located in San Feliciano hill (Orgiano, Monti Berici, Vicenza, NE Italy) (Figure 2). The stratigraphic unit is the so-called "Formazione di Priabona" (late Eocene, Priabonian). The microfossil analysis by nannofossils provided by Beccaro (2003) confirmed the Priabonian age for all layers present in the quarry. The lowest layers are represented by a well-stratified greyish marly-limestone formation including many algae, nummulites, bivalves, several echinoderms, and rare decapod crustaceans [Palaeocarpilius macrocheilus (Desmarest, 1822)]. White-yellowish calcarenites, 6-7 meters thick, overlap the lower layers. These calcarenites including coralline algae, corals, rare mollusc casts, and decapod crustaceans (De Angeli, 2016; Quaggiotto and De Angeli, 2019). Finally, the upper part is represented by marly limestones including nummulites, bryozoans, bivalves, and echinoderms. Many decapod crustaceans collected within the calcarenites were described by several authors (Fabiani, 1911; De Angeli and Garassino, 2002, 2014, in press; De Angeli and Lovato, 2009; De Angeli et al., 2010a; De Angeli, 2016). The studied specimens, subject of this note, were collected from this calcarenite level of the quarry.

\section{Material}

The material includes 10 specimens, housed in the Museo Civico "Domenico Dal Lago" of Valdagno (Vicenza, NE Italy) (MCV). The sizes are expressed in millimetres. Anatomical abbreviations - lcxp: carapace length; wcxp: carapace width; wof: orbitofrontal margin width; wf: frontal width.

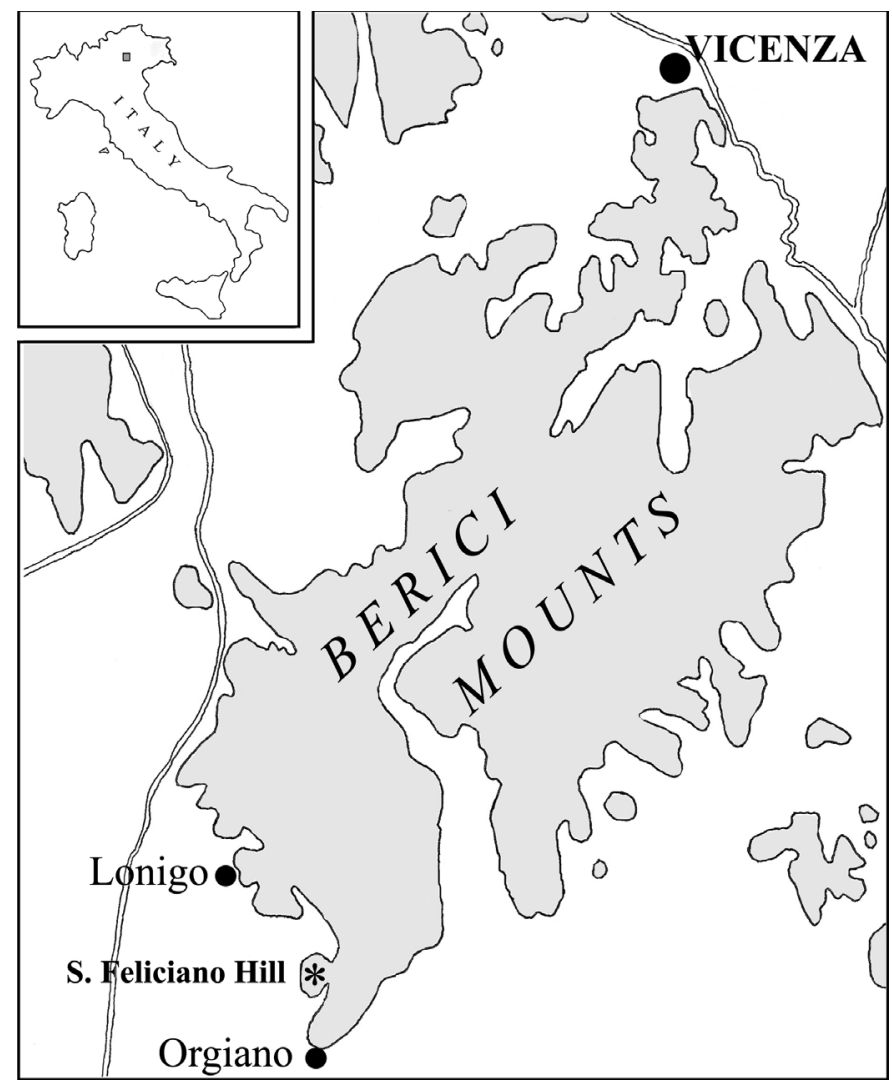




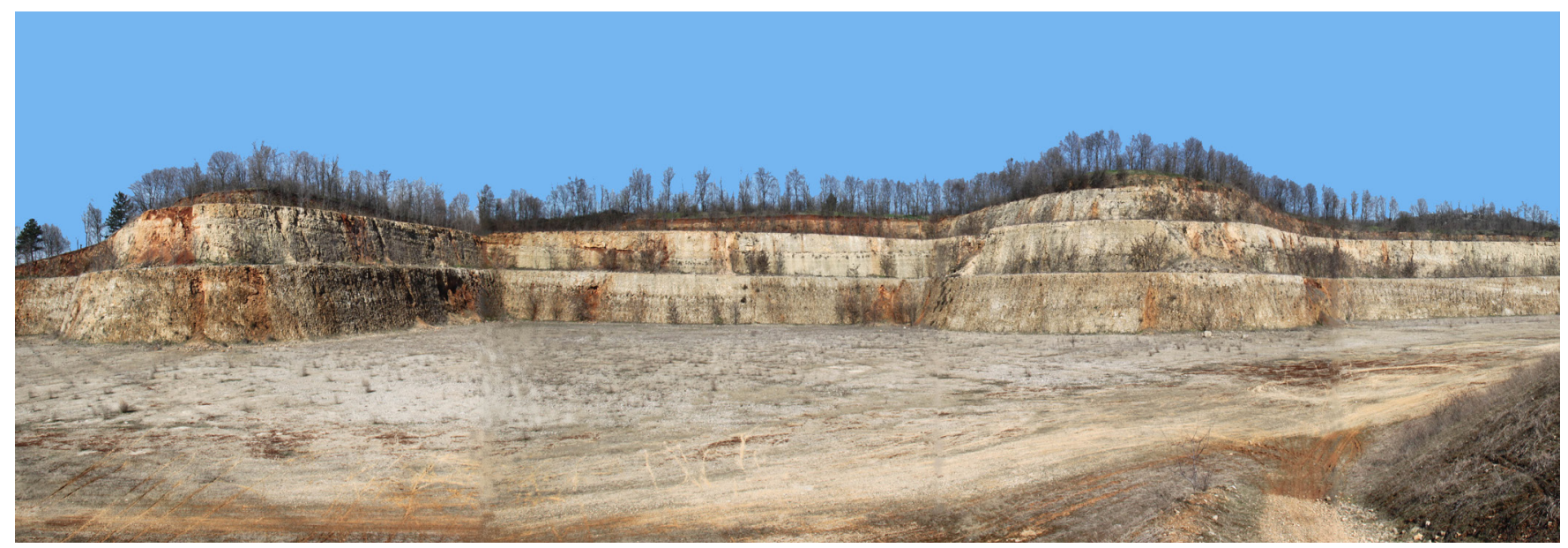

Close-up of the limestones including coralligenous algae and corals from the late Eocene (Priabonian) of San Feliciano hill.

\section{Systematic paleontology}

Order Decapoda Latreille, 1802

Infraorder Brachyura Latreille, 1802

Section Eubrachyura de Saint Laurent, 1980

Subsection Heterotremata Guinot, 1977

Superfamily Majoidea Samouelle, 1819

Family Epialtidae MacLeay, 1838

Subfamily Epialtinae MacLeay, 1838

Genus Bericirinia n. gen.

Diagnosis: Triangular carapace, larger posteriorly, considerably wider than long, convex longitudinally; wide front; short, bifid rostrum, separated by U-shaped notch; preorbital angle blunt; orbits laterally directed; intercalated spine not present; divergent, smooth anterolateral margins; short posterolateral margins, strongly convergent; dorsal regions slightly raised and marked by weak grooves; frontal region with an axial depression running between epigastric lobes and protogastric regions; gastric, cardiac, and branchial regions with some tubercles and ovate swellings; dorsal surface with a scabrous-shaped small granules.

Etymology: from Monti Berici where the studied specimen was collected. Gender: feminine.

Type species: Bericirinia bretoni n. gen., n. sp., by monotypy.

Discussion: Based upon Davie et al., (2015) and Schweitzer et al., (2020), Bericirinia n. gen. shows the main morphological characters shared with many spider crabs, such as the triangular carapace, larger posteriorly; narrow frontal margin; and orbits laterally directed. Moreover, the short, bifid rostrum and the lacking of the intercalated spine allow to assign the new genus to the Epialtidae MacLeay, 1838. Schweitzer et al., (2020) provided a new classification of the Majoidea and within the Epialtidae which includes five fossil genera (Epialtus H. Milne Edwards, 1834; Bolcapisa Beschin, Busulini and Tessier in Beschin et al., 2016; Eoinachoides Van Straelen, 1933; Nanomaja Müller and Collins, 1991; Panticarcinus Collins and Saward, 2006) and one extant-fossil genus (Pugettia Dana, 1851), Panticarcinus from the early Eocene (Ypresian) of UK is the only genus which shows affinities with Bericirinia $\mathrm{n}$. gen. Indeed, both genera share the triangular carapace, larger posteriorly; oblique, divergent anterolateral margins; and dorsal regions with swellings and tubercles. Panticarcinus, however, differs from the new genus in having the carapace longer than wider and elongate single rostrum.

\section{Bericirinia bretoni $\mathrm{n}$. gen., n. sp.}

Figure 3

Diagnosis: as for the genus.

Etymology: the species is named in honour of Gérard Breton (1944-2020), in recognition of 
his major contributions to the knowledge of the palaentology and invertebrate fossils.

Holotype: MGV.2021/003-I.G.21.23, by monotypy.

Type locality: San Feliciano hill (Orgiano, Monti Berici, Vicenza, NE Italy).

Geological age: late Eocene (Priabonian).

Material and measurements: one carapace in dorsal view (MCV.2021/003-I.G.21.23 - lcxp: $32.8 \mathrm{~mm}$, wcxp: $34.2 \mathrm{~mm}$, wof: $18 \mathrm{~mm}$ ).

Description: Triangular carapace, convex longitudinally, larger posteriorly, slightly wider than long $(\mathrm{cxp} / \mathrm{wcxp}=0.95)$, widest between angles of antero- and posterolateral margins; wide front; short, bifid rostrum, separated by
U-shaped notch; preorbital angle blunt; orbits laterally directed; divergent, elongate, and smooth anterolateral margins; short posterolateral margins, strongly convergent; relatively wide posterior margin, partially preserved; dorsal regions slightly raised and marked by shallow grooves; frontal region depressed axially; frontal axial depression running along epigastric and protogastric regions; epigastric lobes with two ovate swellings; raised protogastric regions with three swellings; relatively raised metagastric regions with two swellings; narrow, depressed urogastric region; cardiac region well marked by branchiocardiac grooves laterally, with two swellings; branchial region marked anteriorly by cervical groove with one strong
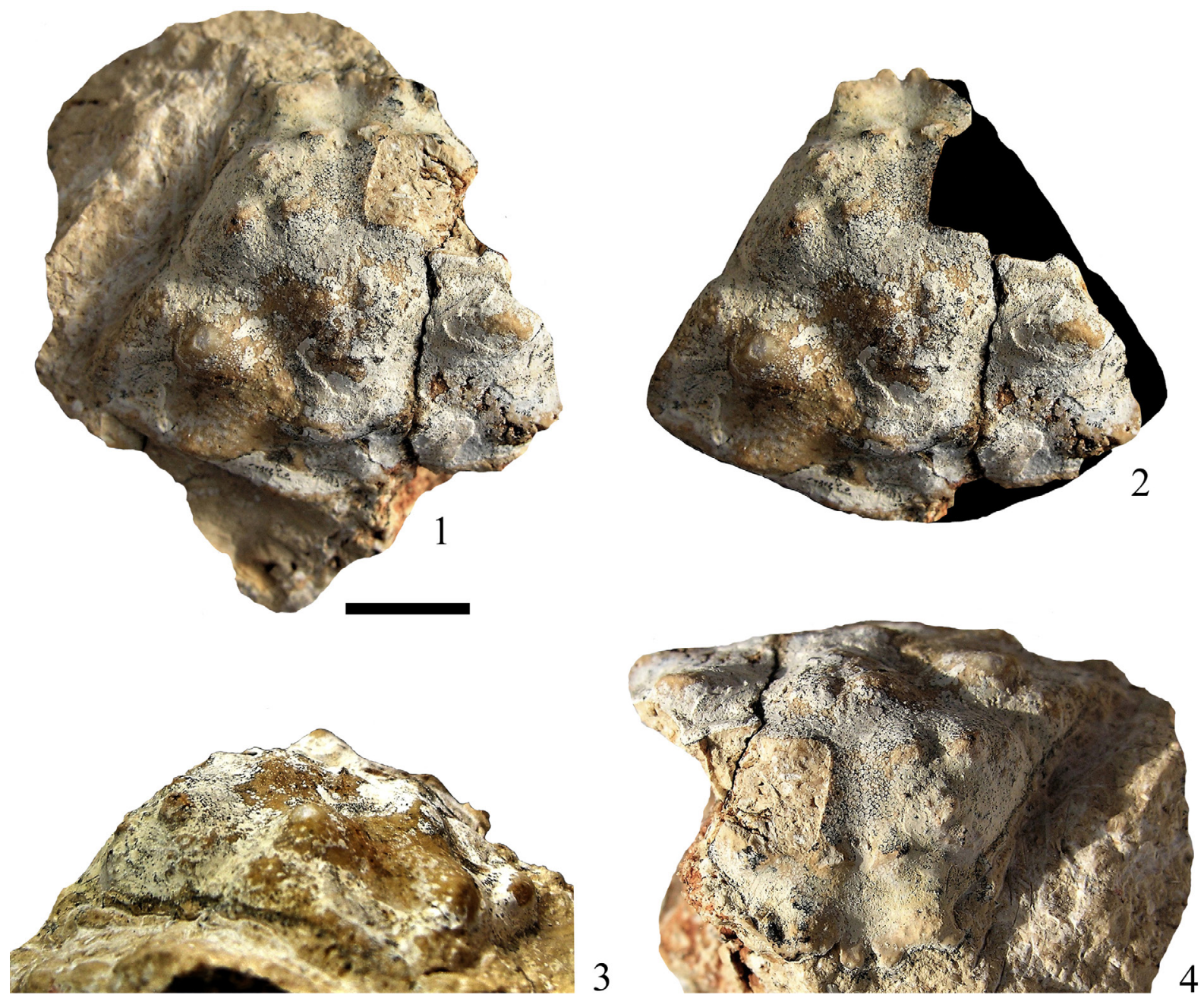

Figure 3 Bericirinia bretoni n. gen., n. sp., holotype, MCV.21/003-I.G.21.23; 1. dorsal view; 2. dorsal digital reconstruction; 3. lateral view; 4. frontal view. Scale bar equals $5 \mathrm{~mm}$. 
epibranchial swelling, one weakly raised transverse mesobrachial swelling, and one weakly transverse metabranchial swelling; dorsal surface with a scabrous-shaped small granules.

Superfamily Dairoidea Serène, 1965

Family Dairidae Ng and Rodriguez, 1986

Genus Orgianocarcinus nov.

Diagnosis: Obovate, convex carapace, wider than long; narrow front, slightly downturned and axially depressed; round orbits having supraorbital margin with two narrow fissures; convex anterolateral margin with 7 spines; short, concave posterolateral margin with 6-7 spines; straight posterior margin; well-distinct dorsal regions with large, obovate or rounded crater-shaped lobules, surrounded by smaller tubercles.

Type species: Orgianocarcinus bericus n. gen., n. sp., by monotypy.

Etymology: from San Feliciano hill Orgiano, where the studied specimens have been collected and carcinus $=$ crab. Gender: masculine.

Discussion: The main morphological characters of the studied specimens fit those of the Dairidae Ng and Rodriguez, 1986. Indeed, the rounded shape of the orbits, with raised, tuberculate supraorbital margin; bilobate front, slightly downturned; and antero- and posterlateral margins with spines are shared with the extant and fossil Daira De Haan, 1833, well known from the Paleogene of Veneto with several species (De Angeli and Garassino, 2006; De Angeli et al., 2019). Orgianocarcinus n. gen. differs, however, in having dorsal regions with some large obovate or rounded crater-shaped tubercles (vs. dorsal regions with many small mushroom-shaped lobules uniformly arranged in Daira). Although the studied specimen lacks the ventral parts, useful for its systematic assignment, the closer affinities are with the representatives of the Dairidae to which it is confidentially assigned.

The ornamentation with large obovate or rounded crater-shaped lobules, resembling the coral look, could be a perfect camouflage system for Orgianocarcinus $\mathrm{n}$. gen. which lived within the corals.

\section{Orgianocarcinus bericus n. gen., n. sp.}

Figure 4

Diagnosis: as for the genus.

Etymology: The trivial name alludes to Monti Berici where the studied specimens have been discovered.

Holotype: MGV.21/008-I.G.21.28.

Paratypes: MCV.21/004-I.G.21.24;

MGV.21/ 005-I.G.21.25;MCV.21 /006-I.G.21.26;

MCV.21 / 007-I.G.21.27; MCV.21/009-I.G.21.29;

MCV.21 / 010-I.G.21.30.

Geological age: late Eocene (Priabonian).

Type locality: San Feliciano hill (Orgiano, Monti Berici, Vicenza, NE Italy).

Material and measurements: seven specimens with well-preserved carapace (MCV.21 /004I.G.21.24 - lcxp: 8.2; wcxp: 11.4; wof: 6; wf: 4.2; MCV.21/005-I.G.21.25 - lcxp: 8.4; wcxp: 11.8; MCV.21/006-I.G.21.26 - lcxp: 7.7; wcxp: 10.8; wof: 5.8; MGV.21/007-I.G.21.27 - lcxp: 4.9; wcxp: 6.9; MCV.21/008-I.G.21.28 - wcxp: 9.4; MGV.21/009-I.G.21.29 - wcxp: 8; MGV.21/010I.G.21.30 - lcxp: 5; wcxp: 7).

Description: Obovate carapace, convex in both sections, above all longitudinally, wider than long $(\operatorname{lcxp} /$ wcxp $=0.71)$; wide orbitofrontal margin half of maximum carapace width; front weakly protruded beyond orbits, slightly downturned and axially depressed; round orbits; raised supraorbital margin with two narrow fissures; preorbital angle with one tubercle; medial orbital tooth with one tubercle; subtriangular extraorbital tooth; convex anterolateral margin with 7 spines; short, slightly concave posterolateral margin with 6-7 spines; straight posterior margin, as wide as front; dorsal regions well marked by grooves; frontal region with medial longitudinal depression; epigastric lobes with two ovate swellings; slightly raised protogastric regions with tubercles; subtriangular, elongate mesogastric region with one longitudinal, ovate lobe; well-distinct metagastric region with one large ovate lobe; subpentagonal cardiac region with two lobes anteriorly and one lobe posteriorly; depressed intestinal region with a 

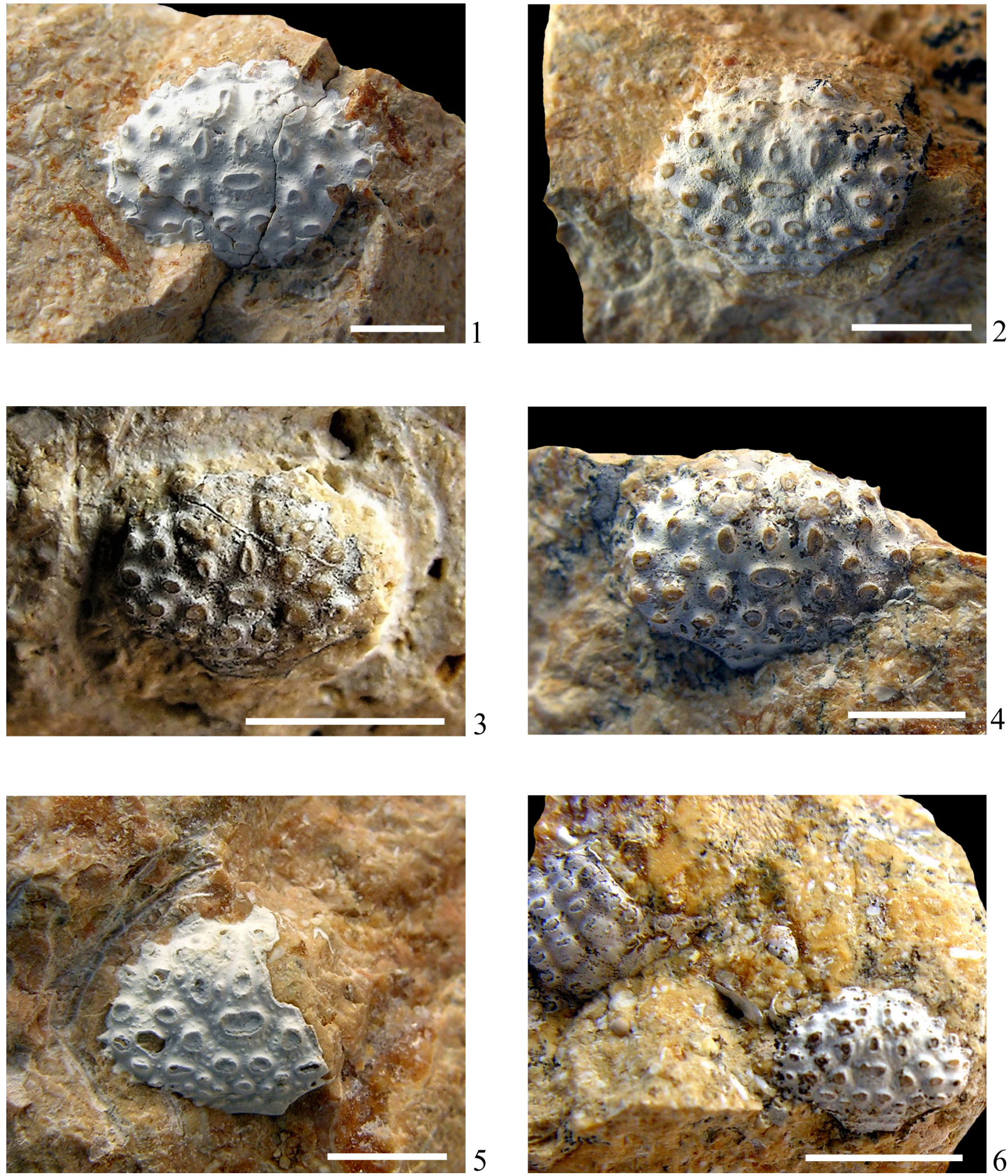

Figure 4 Orgianocarcinus bericus n. gen., n. sp., 1. holotype, MCV.21/008-I.G.21.28, dorsal view; 2. paratype, MCV.21/004-I.G.21.24, dorsal view; 3. paratype, MCV.21/010-I.G.21.30, dorsal view; 4. paratype, MCV.21/006-I.G.21.26, dorsal view; 5. paratype, MCV.21/009I.G.21.29, dorsal view; 6. paratype, MCV.21/007-I.G.21.27, dorsal view. Scale bar equals $5 \mathrm{~mm}$. 
transverse row of 6-7 tubercles; triangular hepatic regions well marked by cervical groove with three lobes; branchial regions with 4 epibranchial lobes, 4 mesobranchial lobes, and three smaller metabranchial lobes.

Cephalic and thoracic appendages and ventral parts not preserved.

Superfamily Xanthoidea MacLeay, 1838 (incertae sedis)

Genus Actaeites Müller and Collins, 1991

Type species: Actaeites lobatus Müller and Collins, 1991, by monotypy.

Fossil species: Actaeites lobatus Müller and Collins, 1991.

\section{Actaeites lobatus Müller and Collins, 1991}

Figure 5

Actaeites lobatus Müller and Collins, 1991: 70, fig. 4c, Pl. 4, figs. 9, 10.

Actaeites lobatus - Karasawa and Schweitzer, 2006: 50. - Beschin et al., 2007: 56, Pl. 9, figs. 2a-b, 3, 4. - De Angeli and Beschin, 2008: 32, fig. 10, Pl. 4, fig. 4. - De Angeli et al., 2010b: 167, fig. 13.
- Schweitzer et al., 2010: 129. - Beschin et al., 2015: 93, Pl. 7, fig. 4. - Beschin et al., 2016: 137, Pl. 17, fig. 8. - Beschin et al., 2018: 196, fig. 128a, b. - De Angeli et al., 2019: 37.

Geological age: late Eocene (Priabonian).

Locality: San Feliciano hill (Orgiano, Monti Berici, NE Italy).

Material and measurements: two specimens with well-preserved carapace (MCV.21/001I.G.21.21 - lcxp: 10; wcxp: 12; MCV.21/002I.G.21.22 - lcxp: 15.1, wcxp: 29; wo-f: 14.8; wof: 8).

Emended diagnosis: Convex carapace, wider than long; bilobate front, depressed axially, with small marginal spines; orbits moderately wide, separated from the front by a deep groove; supraorbital margins with two fissures; convex anterolateral margins with three spines (excluding the extraorbital spine); dorsal regions of the carapace covered by small tubercles uniformly arranged, marked by smooth grooves.

Discussion: Actaeites lobatus was described based upon the morphological characters of the holotype (MAFI EF-22.1 [M.91-153]) from the Priabonian of Budapest (Müller and Collins, 1991). The orbitofrontal margin poorly preserved and the lacking of ventral parts did not allow a right systematic assignment of this species (Kara-
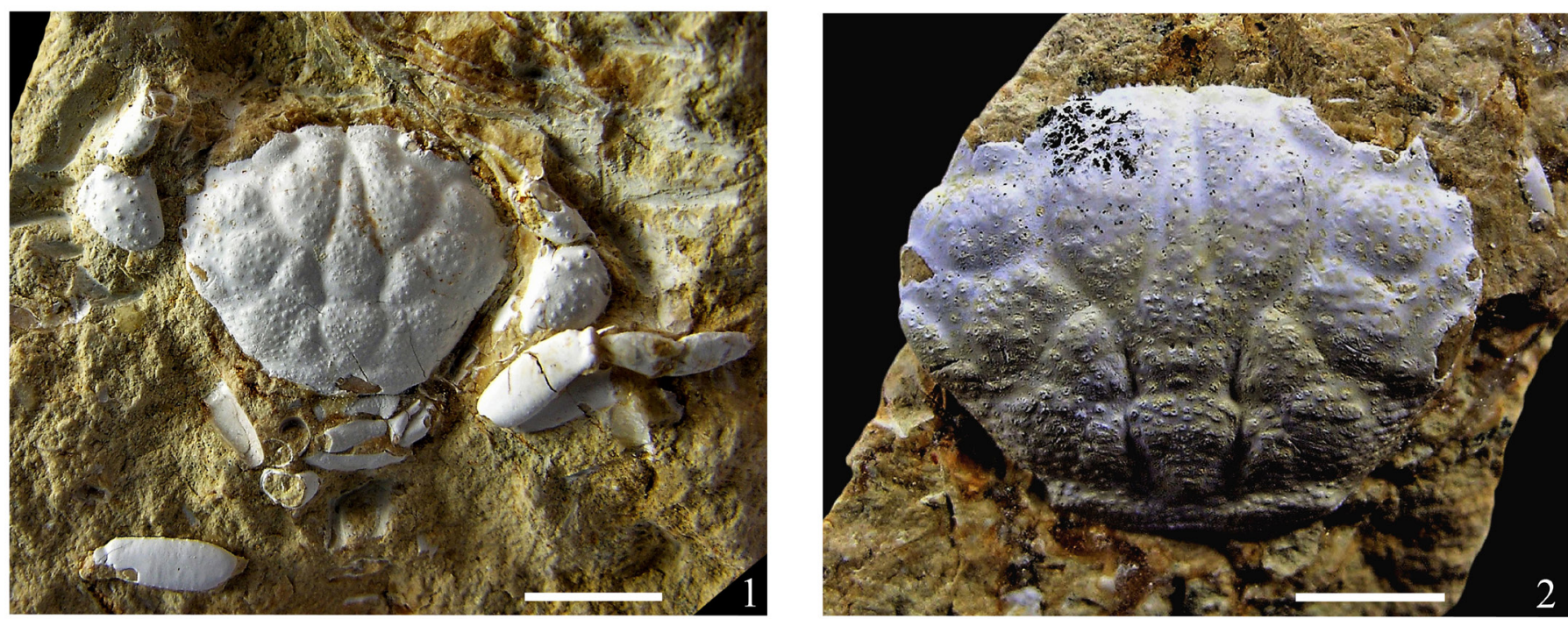

Figure 5 Actaeites lobatus Müller and Collins, 1991, 1. MCV.21/001-I.G.21.21, dorsal view; 2. MCV.21/002-I.G.21.22, dorsal view. Scale bar equals $5 \mathrm{~mm}$. 
sawa and Schweitzer, 2006). Fortunately the studied specimens preserved the anterior part of the carapace, lacking in the holotype, allowing to amend the original diagnosis. Moreover, one studied specimen (MCV.21/001-I.G.21.21) preserves incomplete chelipeds, walking legs, and three male pleonal somites. The chelipeds have carpus and propodus covered by small tubercles. The dorsal regions of the carapace are covered by small tubercles uniformly arranged, marked by smooth grooves.

Except the Priabonian of Hungary, this species has been recorded from the early Eocene (Ypresian) of Gecchelina di Monte di Malo (Vicenza), Vestenanova and Zovo di Bolca (Verona); from the late Eocene (Priabonian) of Campolongo di Val Liona and San Feliciano Hill (Vicenza); and from the early Oligocene of Soghe and Bernuffi di Montecchio Maggiore (Vicenza) (Beschin et al., 2007, 2015, 2016, 2018; De Angeli and Beschin, 2008; De Angeli et al., 2010b).

\section{Conclusions}

The previous reports of decapod crustaceans from the late Eocene of San Feliciano hill include anomurans [Galathea berica De Angeli and Garassino, 2002, Acanthogalathea parva Müller and Collins, 1991, A. feldmanni De Angeli and Garassino, 2002, Palaeomunida defecta Lőrenthey, 1901, P. multicristata De Angeli and Garassino, 2002, Sadayoshia pentacantha (Müller and Collins, 1991), Beripetrolisthes mulleri De Angeli and Garassino, 2002, Eopetrolisthes striatissimus (Müller and Collins, 1991), Lobipetrolisthes blowi De Angeli and Garassino, 2002, Longoporcellana lobata De Angeli and Garassino, 2002, Petrolisthes bittneri De Angeli and Garassino, 2002, Pisidia dorsosinuosa De Angeli and Garassino, 2002, Spathagalathea minuta De Angeli and Garassino, 2002], brachyurans (Eogarthambrus guinotae De Angeli, Garassino and Alberti, 2010a, Phlyctenodes dalpiazi Fabiani, 1911, Spathanomus felicianensis De Angeli, 2016; Caporiondolus bericus De Angeli, 2016), achelata (Palinurellus bericus De Angeli and
Garassino, 2014), and isopods (Sphaeroma gasparellai De Angeli and Lovato, 2009) (Fabiani, 1911; De Angeli and Garassino, 2002, 2014; De Angeli and Lovato, 2009; De Angeli et al., 2010a; De Angeli, 2016). Moreover, a carapace of Lobipetrolistes blowi with isopod (bopyrid) infestation was recorded by Ceccon and De Angeli (2013).

Three new brachyurans Bericirinia bretoni $\mathrm{n}$. gen., n. sp., Orgianocarcinus bericus n. gen., n. sp. and Actaeites lobatus Müller and Collins, 1991) increase the knowledge of the decapod assemblage of San Feliciano hill. The fossiliferous level which preserves the decapod crustaceans is rich of coralline algae, corals, rare molluscs, pointing out the presence of a coral reef during the late Eocene on the southeastern side of Monti Berici (De Angeli and Beschin, 2004; Beschin et al., 2018). Some species recorded in the decapod assemblage of San Feliciano hill were previously reported from the late Eocene of Hungary by Müller and Collins (1991).

\section{Acknowledgements}

We wish to thank Bernadetta Pallozzi, Museo Civico "Domenico Dal Lago" di Valdagno (Vicenza), to make available the specimens for study; Livia Beccaro, Dipartimento di Geoscienze dell'Università di Padova, for the stratigraphical information of San Feliciano hill; and Francisco J. Vega, Instituto de Geología, Universidad Nacional Autónoma de México, Ciudad Universitaria, Coyoacán, Mexico, and Àlex Ossó, Llorenç de Villalonga, 17B, Tarragona, Catalonia, for careful review and criticism.

\section{References}

Beccaro, L., 2003, Revisioni stratigrafiche nel Paleocene del Veneto occidentale: Dottorato di Ricerca in Scienze della Terra, Ciclo $\mathrm{XVI}^{\circ}$, Università degli studi di Padova, Dipartimento di Geologia, Paleontologia e Geofisica. Unpublished Thesis. 
Beschin, G., Busulini, A., De Angeli, A., Tessier, G., 2007, I Decapodi dell'Eocene inferiore di Contrada Gecchelina (Vicenza - Italia settentrionale) (Anomura e Brachyura): Museo di Archeologia e Scienze Naturali "G. Zannato", 9-76.

Beschin, C., Busulini, A., Fornaciari, E., Papazzoni, C.A., Tessier, G., 2018, La fauna di crostacei associati a coralli dell'Eocene superiore di Campolongo di Val Liona (Monti Berici, Vicenza, Italia nordorientale): Bollettino del Museo di Storia Naturale di Venezia, 69, 129-215.

Beschin, C., Busulini, A., Tessier, G., 2015, Nuova segnalazione di crostacei associati a coralli nell'Eocene inferiore dei Lessini orientali (Vestenanova - Verona): Lavori, Società Veneziana di Scienze Naturali, 40, 47-109.

Beschin, C., Busulini, A., Tessier, G., Zorzin, R., 2016, I crostacei associati a coralli nell'Eocene inferiore dell'area di Bolca: Memorie del Museo Civico di Storia Naturale di Verona, 2 serie, Sezione Scienze della Terra, 9, 13-168.

Ceccon, L., De Angeli, A., 2013, Segnalazione di decapodi eocenici infestati da parassiti isopodi (Epicaridea) (Vicenza, Italia settentrionale): Lavori, Società Veneziana di Scienze Naturali, 38, 83-92.

Collins, J.S.H., Saward, J., 2006, Three new genera and species of crabs from the Lower Eocene of London Clay of Essex, England: Bulletin of the Mizunami Fossil Museum, 33, 67-76.

Dana, J.D., 1851, Conspectus Crustaceorum quae in Orbis Terrarum circumnavigatione, Carolo Wilkes e Classe Reipublicae Foederatae Duce, lexit et descripsit. Pars VI: American Journal of Science and Arts, 11(31), 268-274.

Davie, P.J.F., Guinot, D., Ng, P.K.L., 2015, Systematics and classification of Brachyura: Crustacea, 9C (71-18), 1049-1130.

DeAngeli,A., 2016, Nuovi crostacei Cymonomidae (Decapoda: Brachyura) dell'Eocene dei Monti Berici (Vicenza, Italia settentrionale): Studi Trentini di Scienze Naturali, 95, 25-32.

De Angeli, A., Beschin, C., 2004, Nucilobus bericus sp. nov., nuovo crostaceo Leucosiidae
dell'Eocene superiore del Veneto (Vicenza - Italia settentrionale): Lavori, Società Veneziana di Scienze Naturali, 29, 119-122.

DeAngeli,A.,Beschin, C., 2008, CrostaceiDecapodi dell'Oligocene di Soghe e Valmarana (Monti Berici, Vicenza - Italia settentrionale): Studi e Ricerche, Associazione Amici del Museo, Museo Civico "G. Zannato”, 15, 15-39.

De Angeli, A., Garassino, A., 2002, Galatheid, chirostylid and porcellanid decapods (Crustacea, Decapoda, Anomura) from the Eocene and Oligocene of Vicenza (N Italy): Memorie della Società italiana di Scienze naturali e del Museo civico di Storia naturale di Milano, 30(3), 1-40.

De Angeli, A., Garassino, A., 2006, Catalog and bibliography of the fossil Stomatopoda and Decapoda from Italy: Memorie della Società italiana di Scienze naturali e del Museo civico di Storia naturale di Milano, 35(1), 1-95.

DeAngeli, A., Garassino, A., 2014, Palinurellus bericus n. sp. (Crustacea, Decapoda, Palinuridae) from the late Eocene (Priabonian) of San Feliciano (Orgiano, Vicenza, northeastern Italy): Natural History Sciences, Atti della Società italiana di Scienze naturali e del Museo civico di Storia naturale in Milano, 1(1), 7-12.

De Angeli, A., Garassino, A., 2021, Report of ethusid crabs (Brachyura, Ethusidae) from the late Eocene of San Feliciano hill (Monte Berici, Vicenza, NE Italy): Neues Jahrbuch fur Geologie und Palaontologie, Abhandlugen, 301(1), 17-23. http://dx.doi. org/10.1127/njgpa/2021/0995

De Angeli, A., Garassino, A., Alberti, R., 2010a, Eogarthalambrus guinotae n. gen. and n. sp. (Decapoda, Brachyura, Parthenopidae) from the Eocene of Vicenza, Italy, in Castro, P., Davie, P., Ng, P., Richer de Forges, B. (eds.), Studies on Brachyura, A Homage to Danièle Guinot: Crustaceana Monographs, 11, 107-116.

De Angeli, A., Garassino, A., Ceccon, L., 2010b, New report of the coral-associated decapods from the "Formazione di Castelgomberto" 
(early Oligocene) (Vicenza, NE Italy): Atti della Società italiana di Scienze naturali e del Museo civico di Storia naturale in Milano, 151(2), 145-177.

De Angeli, A., Garassino, A., Pasini, G., 2019, Catalog and bibliography of the fossil Stomatopoda and Decapoda from Italy (2007-2018): Memorie della Società italiana di Scienze naturali e del Museo civico di Storia naturale di Milano, 45(1), 1-86.

De Angeli, A., Lovato, A., 2009, Sphaeroma gasparellai n. sp. (Isopoda, Flabellifera, Sphaeromatidae), nuova specie di isopode dell'Eocene superiore dei Monti Berici (Italia settentrionale): Lavori, Società Veneziana di Scienze Naturali, 34, 101-104.

De Haan, H.M. 1833-1849, Crustacea, in Siebold, P.F. von (ed.), Fauna Japonica, sive Descriptio animalium, quae in itinere per Japoniam, jussu et auspiciis superiorum, qui summum in India Batavia imperium tenet, suscepto, annis 1823-1830 collegit, notis, observationibus a adumbrationibus illustravit: Lugduni Batavorum [Leiden], J. Müller et Co, 1-8. https://doi.org/10.5962/bhl.title.124951

Desmarest, A. G., 1822, Les crustacés proprement dits, in Brogniart, A., Desmarest, A.G. (eds.), Histoire naturelle des crustacés fossiles sous les rapports zoologique et géologiques. F.G. Levrault, Paris, 67-142.

Fabiani, R., 1911, Di una nuova specie di Phlyctenodes (Phl. Dalpiazi) dell'Oligocene dei Berici: Bollettino del Museo Civico di Vicenza, 1(3), 3-6.

Guinot, D., 1977, Proposition pour une nouvelle classification des Crustacés Décapodes Brachyoures: Comptes Rendus hebdomadaires des Séances de l'Académie des Sciences, (D), 285, 1049-1052.

Latreille, P.A., 1802-1803, Histoire naturelle générale et particulière, des Crustacés et des Insectes. Ouvrage faisant suite aux ouvres de Leclerc de Buffon, et partie du Cours complet d'Histoire naturalle rédigé par C.S. Sonnini, membre de plusieurs Société savantes: Paris (Dufart), 5, 1-407; 6,1-391.
Lőrenthey, E., 1901, Andorina und Darányia, zwei neue Brachyuren-Gattungen aus Ungarn: Mathemathische und Naturwissenschaftliche Berichte aus Ungarn, 17, 328-336.

Karasawa, H., Schweitzer, C.E., 2006, A new classification of the Xanthoidea sensu lato (Crustacea: Decapoda: Brachyura) based on phylogenetic analysis and traditional systematics and evaluation of all fossil Xanthoidea sensu lato: Contributions to Zoology, 75(1-2), 23-73.

MacLeay, W.S., 1838, On the Brachyurous Decapod Crustacea. Brought from the Cape by Dr. Smith. Illustrations of the Zoology of South Africa; consisting chiefly of figures and descriptions of the objects of natural history collected during an expedition into the interior of South Africa, in the years 1834, 1835, and 1836; fitted out by "The Cape of Good Hope Association for Exploring Central Africa:" together with a summary of African Zoology, and an inquiry into the geographical ranges of species in that quarter of the globe, published under the Authority of the Lords Commissioners of Her Majesty's Treasury, Invertebratae. IV (1849): London, Smith, Elder \& Co., 53-71.

Milne Edwards, H., 1834-1840, Histoire naturelle des crustacés, comprenant l'anatomie, la physiologie, et la classification de ces animaux: Paris, Imprimerie de Fain \& Thunot, 532 p. https://doi.org/10.5962/bhl.title.16170

Müller, P., Collins, J.S.H., 1991, Late Eocene coral-associated decapods (Crustacea) from Hungary: Contributions to Tertiary and Quaternary Geology, 28, 47-92.

Ng, P.K.L., Rodriguez, G., 1986, New records of Mimilambrus wileyi Williams, 1979 (Crustacea: Decapoda: Brachyura), with notes on the systematics of the Mimilambridae Williams, 1979 and Parthenopidae MacLeay, 1838 sensu Guinot, 1978: Proceedings of the Biological Society of Washington, 99(1), 88-99.

Quaggiotto, E., De Angeli, A., 2019, Segnalazione di Jouannetia sp. (Bivalvia, Pholadidae) 
nell'Eocene dei Monti Berici (Vicenza, Italia settentrionale): Studi e Ricerche, Associazione Amici del Museo, Museo Civico "G. Zannato", 26, 71-74.

Saint Laurent, M. de, 1980, Sur la classification et la phylogénie des Crustacés Décapodes brachyoures. I. Podotremata Guinot, 1977, et Eubrachyura sect. nov: Comptes Rendus hebdomadaires des Séances de l'Académie des Sciences, série III: Sciences, Paris, Serie D, 290, 1265-1268.

Samouelle, G. 1819, The entomologists' useful compendium; or an introduction to the knowledge of British insects, comprising the best means of obtaining and preserving them, and a description of the apparatus generally used; together with the genera of Linné, and modern methods of arranging the Classes Crustacea, Myriapoda, spiders, mites and insects, from their affinities and structure, according to the views of Dr. Leach. Also an explanation of the terms used in entomology; a calendar of the times of appearance and usual situations of near 3000 species of British Insects; with instructions for collecting and fitting up objects for the microscope. London, T. Boys. 496 p.

Schweitzer, C.E., Feldmann, R.M., Garassino, A., Karasawa, H., Schweigert, G., 2010, Systematic list of fossil decapod crustacean species: Crustaceana Monographs, 10, 1-122.

Schweitzer, C.E., Feldmann, R.M., Karasawa, H., 2020, Part R, Revised, Volume 1, Chapter 8T11: Systematic descriptions: Superfamily Majoidea: Treatise Online, 136, 1-31. https://doi.org/10.17161/to.vi.14519

Serène, R., 1965-1966, Notes sur les genres Catoptrus et Libystes et les Catoptrinae: Bulletin du Muséum national d'Histoire naturelle, Paris, série 2, 37(6), 989-1000.

Van Straelen, V., 1933, Sur des Crustacés Décapodes Cénozoïques de Venezuela: Bulletin du Musée Royal d'Histoire Naturelle de Belgique, 9(10), 1-11.

Windsor, A.M., Felder D.L., 2014, Molecular phylogenetics and taxonomic reanalysis of the family Mithracidae MacLeay (Decapoda: Brachyura: Majoidea): Invertebrate Systematics, 28,145-173. 